\title{
IMPLEMENTASI TRI DARMA PERGURUAN TINGGI OLEH DOSEN PAK TAHUN AJARAN 2018/2019 DI STT “KRISTUS ALFA OMEGA” SEMARANG
}

\author{
Tantri Yulia \\ (Dosen Prodi Pendidikan Agama Kristen: tantri703@gmail.com)
}

\begin{abstract}
The main tasks of the lecturer are summarized into three main tasks, namely in the fields of teaching, research and community service. The teaching field is related to the ability of lecturers to deliver teaching material, the research assignment related to the development of knowledge and the field of community service is lecturer service which is a contribution of lecturers in community life by sharing their experiences and knowledge in accordance with the specifications of the fields used for welfare to the community. The limitation of the problem in this study is that there are still lecturers of the Christian Religious Education study program at STT Kristus Alfa Omega Semarang who have not implemented the Tri Darma of Higher Education.The formulation of the problem in this study is how big is the level of implementation of the Tri Darma of Higher Education by PAK lecturers in the academic year 2018/2019 at STT "Kristus Alfa Omega" Semarang? The purpose of the study was to determine the level of implementation of the Tri Darma of Higher Education in the field of teaching by PAK lecturers in the academic year 2018/2019 at STT "Kristus Alfa Omega" Semarang. Research hypothesis: Allegedly Implementation of Higher Education Tri Darma by PAK Lecturers in Academic Year 2018/2019 in STT

"Kristus Alfa Omega" Semarang in the medium category or equal to $60 \%$ of the maximum value not accepted because the results of the calculation above obtained a hypothesis value of $83 \%$ of maximum value.
\end{abstract}

\section{A. PENDAHULUAN}

Tugas pokok dosen diringkas menjadi tiga yaitu dalam bidang pengajaran, penelitian dan pengabdian kepada masyarakat. Bidang pengajaran berkaitan dengan kemampuan dosen dalam menyampaikan materi ajar, tugas penelitian berkaitan dengan pengembangan pengetahuan serta bidang pengabdian kepada masyarakat merupakan pengabdian dosen merupakan sumbangsih dosen dalam kehidupan bermasyarakat dengan membagikan pengalaman dan ilmunya sesuai dengan spesifikasi bidang yang ditekuninya yang digunakan bagi kesejahteraan kepada masyarakat.

Paparan tersebut di atas senada dengan kutipan berikut:

"Salah satu tugas dosen, sebagai tugas profesional yaitu untuk membantu memudahkan mahasiswa untuk belajar. Tugas profesional ini perlu dilakukan secara terencana dan berdasarkan baik melalui pengalaman mengajar, penelitian dan pengabdian kepada masyarakat". Dosen bertanggungjawab untuk membantu mahasiswa dalam proses pembelajaran, bantuan ini diberikan secara terencana melalui pengalaman mengajar, meneliti dan pengabdian kepada masyarakat. Dosen dapat melaksanakan tugasnya dalam mengajar dengan cara: "Menguasai isi atau materi, strategi atau metode, media dan mengembangkan evaluasi ". ${ }^{2}$

Dosen diharapkan memiliki kemampuan mengajar, hal ini dapat dilakukan dengan cara dosen menguasai bahan ajar,

"Bahan ajar adalah seperangkat sarana atau alat pembelajaran yang berisikan materi pembelajaran, metode, batasan-batasan, dan cara mengevaluasi yang didesain secara

Group, 2016), 1.
${ }^{2}$ Ibid., 1.

${ }^{1}$ Punaji Setyosari, Metode Penelitian Pendidikan dan Pengembangan (Jakarta: Prenadamedia 
sistematis, dan menarik dalam rangka mencapai tujuan yang diharapkan, yaitu mencapai kompetensi atau subkompetensi dengan segala kompleksitasnya. Bahan ajar merupakan bagian dari perangkat pembelajaran bagi dosen untuk membantu dirinya dalam meningkatkan hasil belajar mahasiswa".3.

Bahan ajar memuat materi pembelajaran, namun penyampaian bahan ajar ini juga dilengkapi dengan pemilihan metode yang sesuai dengan tujuan pembelajaran. Alat evaluasi juga disesuaikan dengan capaian yang diharapkan. Alat evaluasi ini disusun secara sistematis agar dapat mengukur kemampuan mahasiswa yang sebenarnya. Selain bahan ajar, dosen memilih metode yang sesuai dengan tujuan pembelajaran.

Sebagaimana pendapat berikut: "Guru atau dosen sebagai pendidik kudu bisa memilih metode pembelajaran yang menyenangkan". ${ }^{4}$ Dosen diharapkan dapat menyampaikan bahan ajar dengan menggunakan metode pembelajaran yang menyenangkan agar mahasiswa dapat mengikuti proses pembelajaran dengan baik. Pemilihan metode yang tepat akan memudahkan mahasiswa mencapai tujuan pembelajaran.

Beberapa metode pembelajaran yang dapat digunakan dosen dalam mengajar antara lain: "Prinsip student center learning dapat ditunjukkan dengan penggunaan metode pembelajaran seperti cooperative learning, problem based learning, discovery learning oleh dosen. Metode pembelajaran dapat dikembangkan sendiri oleh dosen yang mengacu pada prinsip student learning center, metode yang sering digunakan dosen adalah presentasi dan diskusi kelas, peer teaching dan small group discussion". Selain memilih metode pembelajaran yang tepat, dosen juga perlu memilih strategi pembelajaran yang tepat.

"Strategi pembelajaran merupakan seperangkat aktivitas yang harus dilakukan oleh dosen dalam menjalani tugas akademiknya sebagai orang yang melakukan transfer of knowledge kepada mahasiswa. Strategi pembelajaran mencakup segala pemanfaatan sumberdaya yang ada guna mempercepat dan mempermudah terjadinya proses pembelajaran pada suatu perguruan tinggi".

Pemilihan strategi pembelajaran yang tepat dapat memudahkan dosen untuk mentransfer ilmu kepada mahasiswa. Selain memilih strategi pembelajaran yang tepat, dosen juga dituntut dapat melakukan evaluasi pembelajaran dengan baik.

"Salah satu tugas guru sesuai dengan Undang-Undang RI No 14 Tahun 2005 tentang guru dan dosen dalah menilai dan mengevaluasi peserta didik. Evaluasi dapat dilakukan dengan menggunakan instrumen hasil belajar. Instrumen merupakan alat ukur yang digunakan untuk melakukan evaluasi proses dan hasil belajar. Instrumen yang digunakan harus memiliki daya beda, valid dan reliable. Guru harus memiliki kemampuan dalam mengembangkan instrumen hasil belajar termasuk teknik penskoran". ${ }^{7}$

Guru dan dosen dalam kutipan di atas memiliki kesamaan tanggung jawab yaitu melakukan evaluasi pembelajaran. Evaluasi ini dilakukan dengan menggunakan instrumen hasil belajar yaitu tes dan non tes. Instrumen ini harus memiliki daya beda (dapat membedakan kemampuan mahasiswa), valid (menggunakan alat ukur yang tepat) dan reliable (memiliki keajegan).

\footnotetext{
${ }^{3}$ Awalludin, Pengembangan Buku Teks Sintaksis Bahasa Indonesia (Yogyakarta: Deepublish, 2017), 4

${ }^{4}$ Amirudin Mahmud, Guru Tak Boleh Sejahtera - Catatan dan Refleksi Seorang Pendidik (Yogyakarta: Deepublish, 2018), 82.

${ }^{5}$ Henri Purbo Waseso, Muhtar Sofyan Hidayat, Mengaplikasikan Kurikulum Berbasis KKNI (Wonosobo: Mangkubumi, 2016), 77.

${ }^{6}$ Syahrizal Abbas, Manajemen Perguruan Tinggi (Jakarta: Kencana, 2008), 152.

${ }^{7}$ Kadek Ayu Astiti, Evaluasi Pembelajaran (Yogyakarta: ANDI Offset, 2017), 49.
} 
Selain memiliki tanggungjawab dalam melaksanakan tugas pendidikan dan pengajaran, dosen juga memiliki tanggungjawab dalam melakukan penelitian.

"Tugas dosen yang harus mendapat perhatian adalah melaksanakan dan mengembangkan karya ilmiah. Kegiatan ini sangat urgen mengingat kegiatan penelitian dan karya ilmiah lain menjadi sarana untuk pengembangan diri secara terus-menerus, atau berkelanjutan. Artinya, kegiatan penelitian ini sangat menuntut keterampilan penelitian dan kesungguhan alam menunaikan penelitian, yang selanjutnya menuntut dosen untuk melakukan deseminasi hasil-hasil penelitiannya. Dengan demikian kegiatan penelitian dan menghasilkan karya ilmiah menjadi kegiatan pengembangan profesional dosen karena hasil-hasil penelitian dan pemikiran-pemikiran yang disampikan melalui forum ilmiah, seminar, simposium atau bentuk konferensi yang lain menjadi sarana dan sangat strategis". 8

Dosen memiliki tugas melaksanakan penelitian yang dapat digunakan bagi pengembangan ilmu pengetahuan dan hal ini membutuhkan keterampilan dosen dalam menulis karya ilmiah. Dosen juga memiliki tanggung jawab untuk melakukan pengabdian kepada masyarakat.

"Pengabdian kepada masyarakat yang dilakukan oleh dosen perlu diterapkan, hal ini adalah kontribusi yang bersifat konkrit yang dapat dirasa oleh masyarakat yaitu dengan adanya penerapan ilmu teknologi yang dikembangkan melalui penelitian. Aktivitas ini harus dilakukan bagi setiap Perguruan Tinggi dan terutama dosen di mana kegiatan ini tidak bersifat mencari keuntungan".

Pengabdian kepada masyarakat oleh dosen adalah sumbangsih yang konkrit bagi masyarakat dan kegiatan ini bersifat tidak mencari keuntungan dan dilakukan dengan sukarela. Pengajaran, penelitian dan pengabdian kepada masyarakat yang terintegrasi dengan baik merupakan kebutuhan mutlak bagi dosen Pendidikan Agama Kristen sekarang ini guna meningkatkan kinerja. Ketercapaian Tri Darma Perguruan Tinggi dilakukan melalui evaluasi yang dilakukan secara terus-menerus agar terjadi peningkatan, baik dalam perencanaan, pelaksanaan, pengontrolan dan pengevaluasiannya.

Namun, dalam pengamatan peneliti di Sekolah Tinggi Teologi Kristus Alfa Omega, peneliti mendapati beberapa masalah berikut: pertama, masih terdapat dosen program studi Pendidikan Agama Kristen di STT Kristus Alfa Omega Semarang yang belum mengimplementasikan Tri Darma Perguruan Tinggi. Kedua, masih terdapat dosen yang belum maksimal dalam melakukan tugas pengajaran, hala ini dibuktikan dengan hal-hal berikut: masih terdapat dosen yang belum menyusun bahan ajar (menyusun, mengevaluasi, mengembangkan).

Ketiga, masih terdapat dosen kurang memenuhi target kehadiran dalam satu semester. Masih terdapat dosen belum menyusun RPP (Rencana Pelaksanaan Pembelajaran). Keempat, masih terdapat dosen kurang menggunakan metode secara bervariasi. Kelima, dosen kurang menerapkan strategi pembelajaran yang bervariasi. Keenam, masih terdapat dosen kurang menyusun evaluasi pembelajaran. Dosen kurang menggunakan media pembelajaran yang bervariasi. Ketujuh, masih terdapat dosen kurang memahami psikologis mahasiswa. Kedelapan, dosen kurang melibatkan mahasiswa dalam penyusunan penelitian. Kesembilan, Masih terdapat dosen kurang memanajemen waktu dengan baik sehingga kurang melakukan pengabdian masyarakat secara rutin.

Berdasarkan fakta-fakta di atas peneliti terdorong untuk melakukan penelitian tentang "Implementasi Tri Darma Perguruan Tinggi oleh Pendidik PAK Tahun Ajaran 2018/2019 di STT "Kristus Alfa Omega" Semarang". Melalui penelitian ini diharapkan dosen dapat

\footnotetext{
${ }^{8}$ Punaji Setyosari, $1-2$.

${ }^{9}$ Afriantoni, Isu-Isu Kritis dalam Pendidikan Tinggi : Sebuah Tinjauan Aktual Terhadap Praktik Pendidikan Tinggi di Indonesia (Yogyakarta: Deepublish, 2016), 47.
} 
meningkatkan dosen dalam melakukan tugas pokok atau Tri Darma Perguruan Tinggi. Peningkatan pelaksanaan tugas dosen bukan hanya meningkatkan diri dosen tetapi juga mempercepat pencapaian visi STT Kristus Alfa Omega Semarang yaitu "Menjadi Sekolah Tinggi Teologi Yang Unggul dan Alkitabiah bercirikan Pentakosta Kharismatik". Keunggulan ini mencakup: the best teacher, the best student and the best infrastructure. Guna mencapai "The Best Teacher", maka dosen perlu meningkatkan kinerjanya.

\section{B. METODOLOGI}

"Penelitian deskriptif adalah penelitian yang dilakukan untuk mengetahui nilai variabel mandiri, tanpa membuat perbandingan atau penghubungan dengan variabel lainnya". ${ }^{10}$ Penelitian ini untuk mengetahui variabel Implementasi Tri Darma Perguruan Tinggi oleh Dosen PAK Tahun Ajaran 2018/2019 di STT "Kristus Alfa Omega" Semarang, tanpa membuat perbandingan atau penghubungan dengan variabel lainnya.

\section{PEMBAHASAN}

1. Pendidikan Dan Pengajaran

a. Dosen Menyusun Bahan Ajar

Setiap dosen yang mengajar mahasiswa, memiliki tanggung jawab untuk menyediakan bahan ajar/buku ajar, "Buku ajar adalah naskah yang ditulis oleh dosen dalam rangka menunjang materi pokok mata kuliah yang diajarkan". Penyusunan bahan ajar ini disesuaikan dengan kebutuhan mahasiswa. Penyusunan bahan ajar bertujuan untuk mencapai standar kompetensi dan kompetensi dasar yang diharapkan oleh pendidik.

"Berikut beberapa pedoman yang dapat digunakan untuk menyusun bahan ajar, yaitu pertama, prinsip relevansi, maksudnya bahan ajar yang dipilih hendaknya ada relasi dengan pencapaian standar kompetensi maupun kompetensi dasar. Kedua, prinsip konsistensi, bahan ajar yang dipilih hendaknya memiliki nilai keajegan. Jadi antara kompetensi dasar kompetensi dasar yang harus dikuasai peserta didik dengan bahan ajar yang disediakan memiliki keselarasan dan kesamaan. Ketiga, prinsip kecukupan, ketika memilih bahan ajar hendaknya dicari yang memadai membantu peserta didik menguasai kompetensi dasar yang diajarkan." 11

Bahan ajar yang disusun hendaknya relevan, konsisten dan dan memenuhi unsur kecukupan. Konsep relevan dalam penyusunan bahan ajar selain disesuaikan dengan standar kompetensi dan komptensi dasar juga disesuaikan dengan kebutuhan sekarang, seperti kutipan berikut,

"Pembaharuan bahan ajar sesuai dengan kebutuhan sekarang sangat dibutuhkan untuk perkembangan peserta didik. Bahan ajar lama harus disusun kembali dengan memperbaharui materi-materi yang dibutuhkan pada kebutuhan sekarang, maka dari itu pemerintah melalui kementerian pendidikan dan kebutuhan selalu melakukan pembaharuan kurikulum dengan tujuan agar materi yang diajarkan sekarang sesuai dengan kebutuhan sekarang".

Bahan ajar ini harus memenuhi empat kompetensi yang diharapkan yaitu kompetensi spiritual, sosial, pengetahuan dan keterampilan yang dibutuhkan peserta didik.

\footnotetext{
${ }^{10}$ Sofyan Siregar, Statistik Parametrik Untuk Penelitian Kuantitatif (Jakarta: Bumi Aksara, 2014), 15.

${ }^{11}$ Andi Prastowo, Menyusun Rencana Pelaksanaan Pembelajaran ( RPP) Tematik Terpadu (Jakarta: Kencana, 2017), 227.

${ }^{12}$ Julia, Isro'atun, Indra Safari, Prosiding Seminar Nasional, (Sumedang: UPI Sumedang Press, 2018) 429.
} 
Bahan ajar harus diperbaharui, hal ini dilakukan dengan alasan sebagai berikut:, "Pembaharuan juga harus dilakukan dalam menyusun bahan ajar yang tidak hanya memaparkan teori semata tetapi harus ada pembaharuan bahan ajar yang dapat menghantarkan peserta didik agar dapat belajar mandiri dan menemukan konsep materi secara mandiri (student center). Konsep pembaharuan ini dapat dilakukan dengan dengan cara penelitian dan pengembangan (research and development) dimana dengan melakukan inovasi (pembaharuan) penelitian untuk menghasilkan bahan ajar yang berorientasi pada peserta didik". ${ }^{13}$

Bahan ajar yang disusun berdasarkan penelitian ini bertujuan untuk menghasilkan bahan ajar yang berorientasi pada kebutuhan peserta didik. Bahan ajar juga harus dikembangkan,

"Pengembangan bahan ajar terdiri dari lima kegiatan inti yaitu: pertama, analisis latar belakang dan kebutuhan peserta didik, kedua, desain satu perangkat lingkungan belajar yang efektif, efisien dan sesuai, ketiga, pengembangan seluruh peserta didik berikut pengelolaan materi ajar, keempat, implementasi pembelajaran, kelima, evaluasi formatif dan sumatif". ${ }^{14}$

Pengembangan bahan ajar dapat dilakukan dengan mempertimbangkan beberapa hal yaitu analisis latar belakang, hal ini mencakup tentang kemampuan peserta didik, bahan ajar juga harus disesuaikan dengan lingkungan dimana proses pembelajaran berlangsung, bahan ajar juga diarahkan pada pengembangan peserta didik dalam segala aspek (kognitif, afektif dan psikomotorik), bahan ajar juga perlu diimplementasikan dalam kehidupan praktis dan bahan ajar juga perlu dievaluasi baik evaluasi formatif maupun sumatif.

Bahan ajar ini kemudian digunakan dosen untuk menyusun buku ajar. Buku ajar yang baik memenuhi kriteria berikut:

"Format buku sesuai dengan ketentuan UNESCO, yaitu maksimal ukuran kertas A4 (21 x $29,7 \mathrm{~cm})$, dan minimal menurut Direktorat Jenderal Pendidikan Tinggi A5 $(14,8$ x $21 \mathrm{~cm})$ dengan jumlah minimal 48 halaman.

Memiliki ISBN (International Standard Book Number).

Menggunakan gaya bahasa semi formal.

Struktur kalimat menggunakan S-P-O-K (Subjek-Predikat-Objek-Keterangan).

Mencantumkan TIU dan TIK dan Kompetensi.

Menyertakan pendapat atau mengutip hasil penelitian pakar.

Menggunakan catatan kaki/catatan akhir/daftar pustaka dan jika mungkin menyertakan indeks.

Mengakomodasi hal-hal/ide-ide baru.

Diterbitkan oleh penerbit yang kredibel.

Tidak menyimpang dari falsafah NKRI.

Setiap halaman buku sebaiknya mengindahkan hal-hal berikut ini:

Setiap alinea berisi satu pokok pikiran.

Menggunakan alinea yang pendek.

Menggunakan kalimat-kalimat pendek agar mudah diingat (10-20 kata perkalimat).

Setiap halaman dibuat menarik dan mudah diingat secara verbal maupun visual (mengindahkan kaidah tipografi dan tata letak yang baik).

Setiap halaman berisi teks, grafik/diagram, tabel, gambar (berupa foto atau ilustrasi) inset pengingat dan inset histori.

Tuliskan kalimat motivasi dan inspirasi. ${ }^{15}$

\footnotetext{
${ }^{13}$ Ibid,. 429.

${ }^{14}$ Dewi Salma Prawiradilaga, Mozaik Teknologi Pendidikan E-Learning (Jakarta: Prenadamedia, 2016), 358-359.

${ }^{15}$ An Nuur Budi Utama, Cara Praktis Menulis Buku: Panduan Mudah Akan Membantu Anda Menulis Buku (Yogyakarta: Deepublish, 2014), 6-7.
} 
Buku ajar yang menarik akan meningkatkan minat baca mahasiswa, minat ini akan memupuk kecintaan untuk mempelajari materi yang terdapat dalam buku ajar. Kecintaan terhadap materi ajar ini akan mendorong mahasiswa untuk rajin mempelajari, memahami dan menganalisis, mensintesis dan menerapkan materi yang disampaikan dalam buku ajar.

\section{b. Dosen Menyusun RPP (Rencana Pelaksanaan Pembelajaran)}

"RPP (Rencana Pelaksanaan Pembelajaran) adalah rencana yang menggambarkan prosedur dan pengorganisasian pembelajaran untuk mencapai satu kompetensi dasar yang ditetapkan dalam standar isi dan dijabarkan dalam silabus. Lingkup RPP (Rencana Pelaksanaan Pembelajaran) paling luas mencakup 1 (satu) kompetensi dasar yang terdiri atas 1 (satu) indikator atau beberapa indikator untuk 1 (satu) kali pertemuan atau lebih."16

Penyusunan RPP ini bermanfaat bagi pendidik agar pelaksanaan proses pembelajaran terorganisir sesuai dengan kompetensi yang diharapkan. RPP (Rencana Pelaksanaan Pembelajaran) ini, antara lain mencakup: tujuan pembelajaran yang diharapkan, materi yang digunakan dalam proses pembelajaran, metode yang dipilih untuk digunakan dalam penyampaian materi, sumber belajar yang digunakan dan penilaian hasil belajar yang digunakan.

Adapun landasan pengembangan RPP (Rencana Pelaksanaan Pembelajaran) adalah,

"Peraturan Pemerintah Republik Indonesia Nomer 19 Tahun 2005 tentang Standar Nasional Pendidikan Pasal 20: Perencanaan proses pembelajaran meliputi silabus dan rencana pelaksanaan pembelajaran yang memuat sekurang-kurangnya tujuan pembelajaran, materi ajar, metode pengajaran, sumber belajar, dan penilaian hasil belajar". ${ }^{17}$

Pemerintah memiliki kepedulian terhadap pelaksanaan pembelajaran di Indonesia, hal ini dibuktikan dengan menetapkan standar proses pembelajaran, salah satu standar pelaksanaan standar proses adalah penyusunan RPP (Rencana Pelaksanaan Pembelajaran).

Rencana Pelaksanaan Pembelajaran (RPP) memiliki berbagai manfaat sebagai berikut: "Rencana pengajaran secara otomatis tercatat dan dapat diarsipkan, arsip akan menjadi bekal pendidik dan dapat digunakan dengan penyempurnaan pada tahun ajaran berikutnya, kualitas mengajar pendidik akan terkontrol dan tercatat, kualitas pembelajaran di kelas apat terukur, pendidik mempunyai waktu perencanaan sebuah topik pembelajaran tentang bagaimana sebuah topik disampaikan dengan baik dan menarik, pendidik dapat terus menyempurnakan kualitas RPP (Rencana Pelaksanaan Pembelajaran) masingmasing dari tahun ke tahun. RPP ini dapat dijadikan sebagai bahan pelatihan bagi pendidik baru, sehingga dengan cepat pendidik baru dapat mempelajari variasi RPP yang pernah dibuat, menjadi bahan untuk kajian dan diskusi para pendidik untuk mengembangkan strategi mengajar". ${ }^{18}$

Rencana Pelaksanaan Pembelajaran (RPP) memiliki berbagai manfaat positif baik bagi pribadi pendidik, rekan sejawat pendidik, pendidik baru maupun bagi institusi pendidikan. Beberapa hal yang perlu dipertimbangkan dalam menyusun RPP (Rencana Pelaksanaan Pembelajaran), antara lain: RPP (Rencana Pelaksanaan Pembelajaran) harus disesuaikan dengan silabus, pembelajaran bergantung pada tujuan ateri ajar serta karakteristik peserta didik. Selain hal di atas, "dalam Rencana Pelaksanaan Pembelajaran minimal ada lima komponen pokok, yaitu komponen tujuan pembelajaran, materi pelajaran, metode, media dan sumber

\footnotetext{
${ }^{16}$ Winastwan, Gora dan Sunarto, Pakematik: Strategi Pembelajaran Inovatif Berbasis TIK (Jakarta: Elex Media Komputindo, 2010), 153.

${ }^{17}$ Ibid., 153.

${ }^{18}$ Saifuddin, Pengelolaan Pembelajaran Teoritis dan Praktis (Yogyakarta: Deepublish, 2014),
} 
pembelajaran serta komponen evaluasi". ${ }^{19}$ Kelima komponen dalam Rencana Pelaksanaan Pembelajaran (RPP) ini terkait satu dengan yang lain. Rencana Pelaksanaan Pembelajaran (RPP) memuat tujuan pembelajaran yang dinyatakan dalam standar kompetensi dan kompetensi dasar. Materi ajar adalah bahan yang harus dikuasai oleh peserta didik, strategi pembelajaran dan metode pembelajaran,

"Strategi adalah rancangan untuk mencapai tujuan tertentu; sedangkan metode adalah cara yang digunakan untuk mengimplementasikan strategi. Strategi dan metode pembelajaran harus dirancang sesuai dengan tujuan yang ingin dicapai. Tujuan yang berhubungan dengan bidang kognitif, berbeda strategi dan metode yang digunakan dengan mengajarkan konsep atau prinsip". ${ }^{20}$

Strategi dan metode pembelajaran terkait dengan aspek kognitif, ini terkait dengan komponen-komponen yang lain. Komponen selanjutnya adalah media (alat bantu) dan sumber belajar (segala sesuatu yang dapat dijadikan sumber belajar). Media dan sumber belajar disesuaikan karakteristik peserta didik dan evaluasi untuk mengukur kemampuan peserta didik.

\section{c. Dosen Menggunakan Metode Secara Bervariasi}

"Metode pembelajaran merupakan cara mengajar atau cara menyampaikan materi pelajaran kepada peserta didik yang sedang belajar". ${ }^{21}$ Jadi metode pembelajaran ini menjadi tugas pendidik mempersiapkannya sebelum melaksanakan proses pembelajaran.

Metode pembelajaran yang bervariasi akan menolong peserta didik tidak merasa bosan, "Penggunaan metode pembelajaran yang variatif sangat penting untuk membuat proses pembelajaran tidak membosankan sehingga peserta didik termotivasi untuk belajar dengan baik. Peserta didik yang diajarkan dengan berbagai macam metode dipastikan lebih merasa senang menerima pelajaran",22

Pemilihan metode yang tepat dapat menunjang pembelajaran yang menyenangkan. Pembelajaran yang menyenangkan akan memudahkan pencapaian tujuan pembelajaran.

Rifma berpendapat, "Guru harus hati-hati dalam memilih metode pembelajaran yang konvensional dan terkesan kaku sehingga menghambat kreativitas peserta didik, membangkitkan dan mengembangkan kreativitas peserta didik menjadi sangat penting dilakukan oleh guru dalam mencapai keberhasilan pembelajaran dan pengembangan diri peserta didik". ${ }^{23}$

Pendidik perlu sikap yang berhati-hati dalam memilih metode pembelajaran, sehingga dapat mengembangkan kreativitas peserta didik. Peserta didik yang kreatif akan memiliki kemampuan untuk memecahkan masalah yang menghambatnya untuk mencapai tujuan pembelajaran.

Penggunaan metode pembelajaran mengacu pada beberapa hal, seperti kutipan berikut: "Lectures are a valid method of teaching if the main is to present key information to students. Lectures are appropriate in universal. In those situation, the students generally have the necessary study skills, motivation, attention, span and self management to be able to benefit from this approach". ${ }^{24}$ Pendidik perlu mempertimbangkan kemampuan peserta didik, motivasi, perhatian, rentang waktu yang dimiliki peserta didik dan manajemen diri agar pendidik dapat memanfaatkan metode sebaik mungkin.

\footnotetext{
${ }^{19}$ Wina Sanjaya dan Andi Budimanjaya, Paradigma Baru Mengajar (Jakarta: Kencana, 2017),
}

75.

${ }^{20}$ Ibid., 76.

${ }^{21}$ Suyanto dan Asep Jihad, Menjadi Guru Profesional (Jakarta: Erlangga, 2013), 114.

${ }^{22}$ Ibid., 62.

${ }^{23}$ Rifma, Optimalisasi Pembinaan Kompetensi Paedagogik Guru (Jakarta: Kencana, 2016), 66.

${ }^{24}$ Peter S. Westwood, What Teacher Needs To Know About Teaching Method (Victoria, Acer

Press, 2008). 


\section{d. Dosen Menerapkan Strategi Pembelajaran yang Bervariasi}

Strategi pembelajaran berkaitan dengan metode pembelajaran, "Strategi adalah a plan of operation achieving something, sedangkan metode adalah a way in achieving something" ${ }^{25}$ Jadi strategi pembelajaran adalah perencanaan pembelajaran yang digunakan untuk mencapai tujuan pembelajaran, sedangkan metode pembelajaran adalah cara yang digunakan untuk melaksanakan strategi pembelajaran. Metode merupakan bagian dari strategi pembelajaran yang dapat digabungkan untuk mencapai tujuan pembelajaran. Strategi pembelajaran menentukan keberhasilan pencapaian tujuan pembelajaran dan berwujud pedoman-pedoman serta kerangka kegiatan. "Strategi pembelajaran merupakan pendekatan menyeluruh pembelajaran dalam suatu sistem pembelajaran, yang berupa pedoman umum dan kerangka kegiatan untuk mencapai tujuan pembelajaran, yang dijabarkan dari pandangan falsafah dan atau teori belajar tertentu". ${ }^{26}$

Strategi pembelajaran dapat dimanfaatkan untuk memotivasi peserta didik. Pendidik dapat bercerita, bertanya, berbagi ide, dan berdemonstrasi. Langkah awal dalam menggunakan strategi pembelajaran adalah mempelajari hal-hal yang berkaitan strategi pembelajaran sehingga strategi pembelajaran dapat digunakan secara efektif dalam setiap situasi pembelajaran. Kutipan berikut memaparkan tentang strategi pembelajaran berhubungan dengan berbagai aspek dalam diri peserta didik.

"Each day, in your teaching, you are using different strategies to present information to the students, to make your lessons interesting and to motivate them to learn. You might use storytelling, ask question, share ideas, and demonstrate. So the first step in your learning is to know all about every possible teaching and learning strategy so that you can effectively implement the most appropriate strategy in any given learning situation". ${ }^{27}$

Setiap pertemuan kelas pendidik menggunakan strategi pembelajaran yang berbeda untuk menyajikan informasi kepada peserta didik agar menarik dan memberikan motivasi bagi peserta didik untuk untuk belajar. Hal ini dapat dilakukan dengan cara bercerita, bertanya, berbagi ide, dan berdemonstrasi. Tugas utama pendidik adalah memilih dan menentukan strategi pembelajaran dan dapat menerapkan strategi pembelajaran tersebut secara efektif.

Berbagai strategi pembelajaran yang dapat dimanfaat oleh pendidik dalam proses pembelajaran antara lain: strategi pembelajaran aktif, strategi pembelajaran kooperatif, strategi pembelajaran Quantum Learning, strategi pembelajaran ekspositori, strategi pembelajaran inkuiri, strategi pembelajaran berbasis masalah (problem solving), strategi pembelajaran kontekstual. Masing-masing strategi pembelajaran ini memiliki penekanan yang berbeda dan pendidik dapat menggunakannya secara bervariasi.

Strategi pembelajaran aktif berorientasi pada mahasiswa, sebagaimana kutipan berikut:

"Memilih strategi pembelajaran di sini termasuk strategi pembelajaran konvensional yang berbasis pada dosen maupun strategi pembelajaran aktif yang berbasis pada dosen maupun strategi pembelajaran aktif yang berbasis pada mahasiswa. Pada dasarnya tidak ada strategi yang paling efektif untuk seluruh karakteristik peserta didik dan sumber

\footnotetext{
${ }^{25}$ Wina Sanjaya, Paradigma Baru Mengajar (Jakarta: Kencana, 2017), 112.

${ }^{26}$ Yusufhadi Miarso, Menyemai Benih Teknologi Pendidikan (Jakarta: Prenadamedia Group, 2011), 456.

${ }^{27}$ Diana Whitton, Teaching and Learning Strategies (Melbourne: Cambridge University Press, 2015), 4
} 
belajar, begitu pula dengan penerapan strategi bukan berarti bukan berarti strategi pembelajaran aktif lebih hebat daripada strategi pembelajaran konvensional". ${ }^{28}$

Strategi pembelajaran aktif ini berfokus pada mahasiswa. Pemilihan dan penerapan strategi pembelajaran disesuaikan dengan tujuan pembelajaran yang ditetapkan di awal pembelajaran. Tidak ada strategi pembelajaran yang paling baik, pemilihan strategi pembelajaran yang tepat akan membantu dosen mencapai tujuan pembelajaran.

\section{e. Dosen Melakukan Evaluasi Pembelajaran}

Pendidikan yang menjalankan Tri Darma Perguruan Tinggi, dalam bidang pengajaran, maka tidak dapat dilepaskan dari tanggung jawab evaluasi pembelajaran, sebab evaluasi pembelajaran merupakan bagian dari pembelajaran.

"Assesmen dan evaluasi pendidikan merupakan salah satu variabel dalam proses pendidikan yang dapat memberikan umpan balik (feedback) bagi penyempurnaan pendidikan untuk masa berikutnya, baik berhubungan dengan proses pelaksanaan maupun yang dicapai sebagai salah satu variabel yang menentukan. Assesmen dan evaluasi pendidikan perlu dirancang dengan baik efektif dan efisien dengan merujuk pada kriteria yang sahih dan andal. Baik dalam penyusunan instrumen penetapan prosedur". ${ }^{29}$

Evaluasi pembelajaran merupakan bagian dari evaluasi pendidikan, hal ini berhubungan dengan proses pembelajaran, hal ini perlu dirancang (menggunakan standar ukuran yang jelas, guna mencapai ukuran yang ditetapkan baik berkaitan dengan instumen maupun prosedur) agar dapat memberikan feed back bagi sekolah. Dosen dapat melakukan evaluasi pembelajaran dengan menerapkan prinsip-prinsip evaluasi pembelajaran sebagaimana kutipan berikut:

"Proses penilaian harus merupakan bagian yang tak terpisahkan dari proses pembelajaran, bukan bagian terpisah dari proses pembelajaran. Penilaian harus mencerminkan masalah dunia nyata, bukan masalah dunia sekolah. Penilaian harus menggunakan berbagai unsur, metode dan kriteria yang sesuai dengan karakteristik dan esensi pengalaman belajar. Penilaian harus bersifat holistik yang mencakup semua aspek dari tujuan pembelajaran (kognitif, efektif dan sensorimotorik)". ${ }^{30}$

Evaluasi pembelajaran harus berkaitan dengan proses pembelajaran, penilaian ini berkaitan dengan pengetahuan peserta didik bukan hanya berfokus pada masalah-masalah sekolah tetapi masalah-masalah yang berkaitan dengan dunia di mana peserta didik berkomunitas. Penilaian juga menggunakan berbagai unsur, metode dan kriteria yang jelas dan sesuai dengan karakteristik dan esensi pengalaman belajar. Penilaian ini juga mencakup semua aspek dari peserta didik yaitu aspek kognitif, afektif dan psikomotorik.

Prinsip-prinsip lain yang dapat diterapkan dalam evaluasi pembelajaran, sebagaimana kutipan berikut:

"Objektif berarti penilaian berbasis pada standar dan tidak dipengaruhi faktor subjektivitas penilai. Penilaian berdasarkan standar (prosedur dan kriteria yang jelas). Hal ini dilakukan dengan cara guru akan membuat rubrik atau pedoman dalam membuat skor. Terpadu, penilaian oleh pendidik dilakukan secara terencana, menyatu dengan kegiatan pembelajaran dan berkesinambungan. Ekonomis, berarti penilaian penilaian yang efisien dan efektif dalam perencanaan, pelaksanaan dan pelaporannya. Transparan, berarti prosedur penilaian, kriteria penilaian dan dasar pengambilan keputusan apat diakses oleh semua pihak. Akuntabel, berarti penilaian dapat dipertanggungjawabkan kepada pihak

\footnotetext{
${ }^{28}$ Muhammad Yaumi, Media dan Teknologi Pembelajaran (Jakarta: Prenadamedia Group, 2018), 88

${ }^{29}$ A. Muri Yusuf, Assesmen dan Evaluasi Pendidikan (Jakarta: Kencana, 2017), 8.

${ }^{30}$ Ahmad Susanto, Teori Belajar dan Pembelajaran di Sekolah Dasar (Jakarta: Prenadamedia Group, 2016), 48.
} 
internal sekolah maupun eksternal untuk teknik, prosedur dan hasilnya. Edukatif, berarti mendidik dan memotivasi peserta didik dan pendidik. Sistematis, berarti penilaian dilakukan secara berencana dan bertahap dengan mengikuti langkah-langkah baku. Menyeluruh/komprehensif, berarti penilaian yang dilakukan mencakup seluruh aspek yaitu kognitif, afektif dan psikomotorik. Kontinuitas atau berkesinambungan berarti penilaian yang dilakukan hendaknya secara kontinu. Sahih/valid, yakni penilaian didasarkan pada data yang mencerminkan kemampuan yang diukur sehingga instrumen yang digunakan harus diuji dahulu. Adil, yakni penilaian tidak menguntungkan atau merugikan karena berkebutuhan khusus. Beracuan kriteria, berarti penilaian didasarkan pada ukuran pencapaian kompetensi yang ditetapkan." 31

Prinsip-prinsip evaluasi yang diterapkan dengan tepat, maka akan berdampak peningkatan kepuasan peserta didik terhadap kinerja pendidik. Pendidik bertanggungjawab memberikan penilaian secara objektif atau bebas dari unsur subjektivitas (like and dislike). Penilaian juga dilakukan berkaitan dengan proses pembelajaran, penilaian tidak boleh dipisahkan dari proses pembelajaran. Penilaian dilakukan secara efektif (mencapai tujuan) dan efisien (dengan tenaga dan biaya yang memadai), Penilaian juga dilakukan secara transparan (pihak yang berkepentingan dapat mengakses dengan mudah).

Penilaian dapat dipertanggungjawabkan kepada pihak yang berkepentingan, penilaian bersifat mendidik dan memotivasi mahasiswa untuk meningkatkan kemampuannya, penilaian mencakup semua aspek mahasiswa baik aspek kognitif, afektif dan aspek psikomotorik, penilaian menggunakan alat atau instrumen yang teruji kehandalannya, Penilaian juga bersifat adil, di mana dosen tidak membeda-bedakan mahasiswa.

f. Dosen Menggunakan Media Pembelajaran yang Bervariasi berikut ${ }^{32}$ :

Media pembelajaran diperlukan dalam proses pembelajaran, sebagaimana kutipan

\begin{tabular}{|l|l|l|}
\hline \multicolumn{3}{|c|}{ Manfaat Media Pembelajaran Bagi Pendidik dan Peserta Didik } \\
\hline \multicolumn{1}{|c|}{ Aspek } & \multicolumn{1}{c|}{ Manfaat Media Pembelajaran } \\
\hline $\begin{array}{l}\text { Penyampaian } \\
\text { materi }\end{array}$ & $\begin{array}{l}\text { Mendidik } \\
\text { menjelaskan materi pembelajaran }\end{array}$ & $\begin{array}{l}\text { Memudahkan peserta didik dalam } \\
\text { memahami materi pembelajaran }\end{array}$ \\
\hline Konsep & $\begin{array}{l}\text { Materi yang bersifat abstrak } \\
\text { menjadi konkrit }\end{array}$ & $\begin{array}{l}\text { Konsep materi mudah dipahami } \\
\text { konkrit medianya, konkrit } \\
\text { pemahamannya }\end{array}$ \\
\hline Waktu & $\begin{array}{l}\text { Lebih efektif dan efisien, } \\
\text { mengulang materi pembelajaran } \\
\text { hanya seperlunya saja }\end{array}$ & $\begin{array}{l}\text { Memiliki waktu yang lebih } \\
\text { banyak dalam mempelajari materi } \\
\text { dan menambah materi yang } \\
\text { relevan }\end{array}$ \\
\hline Minat & $\begin{array}{l}\text { Mendorong minat belajar dan } \\
\text { mengajar pendidik }\end{array}$ & $\begin{array}{l}\text { Membangkitkan minat belajar } \\
\text { peserta didik }\end{array}$ \\
\hline Situasi belajar & Interaktif & Multi-aktif \\
\hline Hasil belajar & Kualitas hasil mengajar lebih baik & Lebih mendalam dan utuh \\
\hline
\end{tabular}

Dosen yang memahami manfaat penggunaan media pembelajaran akan memanfaat media pembelajaran sebaik mungkin agar tujuan pembelajaran dapat tercapai secara efektif dan

\footnotetext{
${ }^{31}$ Kadek Ayu Astiti, Evaluasi Pembelajaran (Yogyakarta: ANDI, 2017), 4-5.

${ }^{32}$ Satrianawati, Media dan Sumber Belajar (Yogyakarta: Deepublish, 2018), 9.
} 
efisien. Media pembelajaran dapat memudahkan dosen dalam menjelaskan materi ajar, menjelaskan materi ajar yang abstrak menjadi konkrit, media pembelajaran menolong dosen untuk memanfaatkan waktu secara efektif dan efisien.

Media pembelajaran dapat dimanfaatkan dengan tepat dengan mendasarkannya pada prinsip-prinsip penggunaannya sebagai berikut:

"Pertama, menentukan jenis media dengan tepat, artinya sebaiknya pendidik memilih media yang sesuai dengan tujuan dan bahan pelajaran yang akan diajarkan. Kedua, menetapkan atau memperhitungkan subyek dengan tepat, artinya perlu memperhitungkan penggunaan media sesuai dengan tingkat kematangan/kemampuan peserta didik. Ketiga, menyajikan media yang tepat, artinya teknik dan metode penggunaan media dalam pembelajaran haruslah disesuaikan dengan bahan, metode, waktu dan sarana yang ada. Keempat, menempatkan atau memperlihatkan media pada waktu, tempat dan situasi yang tepat. Artinya kapan dalam situasi mana pada waktu mengajar media digunakan tentunya tidak terus-menerus memperlihatkan". ${ }^{33}$

Penerapan prinsip-prinsip penggunaan media pembelajaran akan menolong pendidik menyampaikan materi pembelajaran dengan baik. Penyampaian materi pembelajaran dengan baik, akan menumbuhkan antusias mahasiswa dalam mengikuti perkuliahan. Perkuliahan menjadi aktivitas yang menyenangkan. Penerapan prinsip-prinsip penggunaan media pembelajaran memudahkan dosen untuk mendorong mahasiswa mencapai tujuan pembelajaran (pencapaian standar kompetensi dan kompetensi dasar).

\section{g. Dosen Memahami Psikologis Mahasiswa}

Dosen yang memahami psikologis mahasiswa akan mengembangkan kemampuan pedagogik secara umum dan secara khusus memahami perkembangan mahasiswa dalam segala aspek (kognitif, sosial, moral) sehingga dosen dapat melaksanakan tugasnya dengan baik dan meningkatkan mutu lulusan. Pemahaman terhadap aspek psikologis mahasiswa juga dapat memudahkan dosen untuk melakukan pendekatan yang diperlukan agar dapat memberikan dorongan positif yang diperlukan bagi mahasiswa guna mengembangkan kemampuannya.

Pendidik diharapkan memiliki kemampuan kondisi psikologis peserta didik agar mampu melakukan pendekatan yang diharapkan dapat menolong peserta didik memiliki kemandirian dalam belajar, sebagaimana kutipan berikut,

"Para pendidik diharapkan mampu memperlakukan peserta didik sesuai dengan sifatsifat-sifat, kebutuhan, karakteristik dan perbedaan-perbedaan individual lainnya. Fokus persoalan pendidikan adalah peserta didik (student centered education) artinya pendidikan adalah suatu proses yang berorientasi pada perubahan psikologis peserta didik. Perlakuan psikologis yang tepat menjadi salah satu faktor utama tercapainya proses pembudayaan (enkulturasi) peserta didik". ${ }^{34}$

Pendidik yang memiliki kemampuan dalam memahami kondisi psikologis peserta didik akan memperlakukan peserta didik sesuai dengan sifat-sifatnya, memperhatikan kebutuhan peserta didik dan memahami perbedaan karakteristik peserta didik dan melakukan pendekatan yang fleksibel sesuai dengan kepribadian peserta didik.

Pendidik diharapkan dapat memahami karakteristik peserta didik, sebagaimana kutipan berikut:

Salah satu karakteristik remaja adalah mencari perkembangan hubungan dengan teman sebaya (peer group). Artinya mulai fase remaja awal sudah memiliki kemampuan

\footnotetext{
${ }^{33}$ Warni Tune Sumar, Strategi Pembelajaran dalam Implementasi Kurikulum Berbasis Soft Skill (Yogyakarta: Deepublish, 2016), 239.

${ }^{34}$ Syamsul Bachri Thalib, Psikologi Pendidikan Berbasis Analisis Empiris Aplikatif(Jakarta: Kencana, 2010), 10.
} 
interaksi sosial yang lebih luas dan mendalam dengan teman sebaya. Minat remaja semakin bertambah dan terarah pada kegiatan yang dilakukan teman sebaya, dorongan untuk diterima dan membentuk kelompok atau komunitas. Kualitas hubungan remaja semakin lama semakin kuat, dari yang semula hanya sebagai teman kemudian menjadi sahabat bahkan membentuk kelompok khusus yang cenderung memunculkan perilaku melanggar norma dan kenakalan remaja (juvenile deliquency). ${ }^{35}$

Mahasiswa di tingkat perguruan tinggi dalam tahap perkembangan hubungan teman sebaya dan menjalin persahabatan, hal ini dapat dimanfaatkan oleh pendidik untuk melakukan strategi pembelajaran kooperatif. Pembelajaran kooperatif ini menekankan kerjasama antar rekan mahasiswa untuk mencapai tujuan pembelajaran yang diharapkan. Model pembelajaran kooperatif ini memiliki ciri-ciri sebagai berikut:

"Pembelajaran kooperatif merupakan model pembelajaran yang mengutamakan kerjasama di antara peserta didik untuk mencapai tujuan pembelajaran. Model pembelajaran kooperatif memiliki ciri-ciri: untuk menuntaskan materi belajarnya, peserta didik belajar dalam kelompok secara kooperatif, kelompok dibentuk dari peserta didik yang memiliki kemampuan tinggi, sedang dan rendah. Jika dalam kelas, terdapat peserta didik yang terdiri dari beberapa ras, suku, budaya, jenis kelamin yang berbeda pula. Pendidik juga memiliki tanggungjawab untuk memberikan bantuan agar peserta didik dapat mengikuti proses pembelajaran.

"Untuk dapat memberikan bantuan agar peserta didik dapat mengikuti pembelajaran yang disajikan oleh pendidik, maka pendidik harus benar-benar dapat memahami ciri-ciri para peserta didik tersebut. Begitu pula pendidik harus mampu mengatur kegiatan pembelajaran mulai dari perencanaan, proses pelaksanaan sampai pada tahap terakhir yaitu penilaian atau evaluasi, sehingga peserta didik secara total dapat mengikuti proses pembelajaran dengan baik tanpa perbedaan yang berarti walaupun dari latar belakang dan kemampuan yang berbeda-beda". ${ }^{36}$

Kutipan di atas menjelaskan pendidik memiliki tanggungjawab memberi bantuan bagi peserta didik dalam mengikuti proses pembelajaran, juga dapat mengevaluasi, sehingga dengan tepat, sehingga walaupun peserta didik memiliki latar belakang yang berbeda-beda namun dapat mengikuti proses pembelajaran dengan baik. Dosen memerlukan kemampuan untuk membantu mahasiswa belajar dengan baik.

Dosen bertindak sebagai fasilitator ketika membantu mahasiswa dalam belajar. Sebagaimana kutipan berikut:

"Proses belajar-mengajar yang harus dikembangkan saat ini adalah peran dosen sebagai fasilitator. Hal ini diperlukan karena proses pembelajaran yang berorientasi kepada guru (teacher oriented). Dosen memberikan atau menyajikan materi pengetahuan (misalkan dalam perkuliahan) kepada mahasiswa serta dosen membantu mahasiswa untuk memahami materi yang telah disajikan". ${ }^{37}$

Dosen bukan hanya bertanggungjawab dalam menyampaikan materi ajar tetapi juga membantu mahasiswa dalam memahami materi ajar yang telah disampaikan. Berbagai cara dapat digunakan oleh dosen untuk membantu mahasiswa memahami materi ajar, antara lain: memberikan contoh, memberikan ilustrasi, menggunakan alat peraga, dll.

\footnotetext{
${ }^{35}$ Ahmad Susanto, Bimbingan dan Konseling di Sekolah: Konsep, Teori dan Aplikasinya
} (Jakarta: Prenadamedia Group, 2018), 77. 2017), 14

${ }^{36}$ Cucun Sunaengsih, Buku Ajar Pengelolaan Pendidikan (Sumedang: UPI Sumedang Press,

${ }^{37}$ C.S Widodo \& Jasmadi STP, Panduan Menyusun Bahan Ajar Berbasis Kompetensi (Jakarta: Elex Media Komputindo, 2008), 41. 
2. Penelitian

a. Dosen Menyusun Penelitian Mandiri

Salah satu tugas dosen adalah melakukan penelitian. Penelitian ini digunakan untuk menemukan pengetahuan baru melalui pengalaman empirik. Dosen yang melakukan penelitian bukan hanya memperkaya pengetahuan atau teori tetapi dosen dapat menggabungkan antara teori dan pengalamannya dalam menemukan masalah-masalah yang riil dan menemukan solusinya. Hal ini dapat dibagikan oleh dosen kepada mahasiswa. Dosen akan dipermudah dalam menyampaikan materi karena memahami persoalan-persoalan yang up to date sesuai dengan bidang yang ditekuninya.

Dosen dapat meningkatkan kepercayaan diri dalam menyampaikan ilmu tersebut kepada mahasiswa karena dosen telah menerapkan ilmu yang ditekuninya di tengah-tengah kehidupan bermasyarakat. Dosen akan mendapatkan pengalaman baru bukan hanya secara teoritis tetapi secara praktis. Dosen yang melakukan penelitian dapat meningkatkan kesejahteraan orang lain, sebab melalui penemuannya dalam penelitian dapat dimanfaatkan bagi peningkatan kesejahteraan masyarakat sesuai dengan bidang yang ditekuni.

\section{b. Dosen Menyusun Penelitian Bersama Mahasiswa}

Dosen memiliki tanggungjawab inti antara lain: pengajaran, penelitian dan pengabdian kepada masyarakat. Bidang penelitian bukan hanya penelitian mandiri tetapi juga penelitian kelompok yaitu dosen dengan mahasiswa. Dosen memiliki tanggung jawab untuk mengembangkan kemampuan mahasiswa dalam bidang penelitian guna meningkatkan kemampuan mahasiswa dalam meneliti guna mengembangkan ilmu pengetahuan.

"Dosen diharapkan menjadi academic leader yang memiliki tipe: pertama, dosen mampu mengembangkan keilmuan lalu mempunyai pengikut, membuat penelitian dan menghasilkan suatu produk. Kedua, dosen membuat penelitian, namun juga memikirkan pendanaan riset mahasiswa. Ketiga, dosen menjadi pemimpin di perguruan tinggi yang mempunyai visi dan misi mahasiswa yang berkualitas". ${ }^{38}$

Kutipan di atas menjelaskan dosen memiliki tanggungjawab mengembangkan keilmuan dan mempunyai pengikut (melibatkan mahasiswa) dalam melakukan penelitian. Dosen menolong mahasiswa cara menemukan masalah yang perlu urgent untuk diteliti,

"Topik penelitian dapat ditemukan dengan cara-cara berikut: pertama, pengalaman sehari-hari yang ditemui oleh peneliti (memiliki kepekaaan dalam menangkap masalah). Hal ini membutuhkan kepedulian dari peneliti. Kedua, keingintahuan peneliti, rasa ingin tahu menjadi bahan bakar bagi pencarian sebuah penelitian. Ketiga, melalui pengajuan pertanyaan, mengapa, apa bedanya, apa ada hubungannya". 39

Hal berikut yang dilakukan dosen adalah membantu mahasiswa untuk mengidentifikasi masalah,

"Mengidentifikasi masalah berarti mengenali masalah yaitu dengan cara mendaftar faktor-faktor berupa permasalahan. Mengindentifikasi masalah penelitian bukan hanya sekedar mendaftar sejumlah masalah, melainkan juga kegiatan ini, lebih daripada itu karena masalah yang telah dipilih hendaknya memiliki nilai yang sangat penting atau signifikansi untuk dipecahkan., 40

\footnotetext{
${ }^{38}$ Firdiyanto, Kaum Intelektual di Bawah Kaki Kekuasaan (Lampung, Gre Publishing, 2017).

${ }^{39}$ Patrisius Istiarto Djiwandono, Meneliti Itu Tidak Sulit: Metodologi Penelitian Sosial dan Pendidikan Bahasa (Yogyakarta: Deepublish 2015), 2-3.

${ }^{40}$ Punaji Setyosari, Metode Penelitian dan Pengembangan (Jakarta: Prenada Media Group,2016), 96.
} 
Mengidentifikasi masalah bukan hanya mendaftar masalah-masalah yang ditemukan tetapi memilih masalah yang layak untuk diteliti. Setelah masalah diidentifikasi, masalah kemudian dibatasi atau dipilih, masalah yang layak untuk diteliti.

"Batasan masalah yaitu membatasi atau membatasi ruang lingkup masalah yang telah teridentifikasi. Batasan masalah ini berguna untuk mengidentifikasi faktor mana saja yang termasuk dalam ruang lingkup masalah penelitian. Pemilihan batas masalah yang hendak diteliti haruslah didasarkan pada alasan yang tepat, baik alasan teoritis maupun alasan praktis. Yang harus diperhatikan peneliti sebelum menentukan batasan masalah. Masalah yang diteliti hendaknya dalam kemampuan peneliti (managable problems); masalah dibatasi hendaknya dapat diuji berdasarkan data-data yang mudah diperoleh di lapangan (obtainable problems); masalah yang dibatasi hendaknya cukup penting untuk diselidiki (significance problems); masalah yang batasi hendaknya cukup menarik minat peneliti (interested problems)". ${ }^{41}$

Batasan masalah hendaknya sesuai dengan alasan yang tepat, sesuai dengan kemampuan peneliti, masalah hendaknya dapat diuji, masalah hendaknya cukup penting dan masalah cukup menarik minat.

Setelah masalah dibatasi, maka kemudian dirumuskan.

"Problem formulation atau research problem adalah suatu rumusan yang mempertanyakan suatu fenomena, baik dalam kedudukannya sebagai fenomena mandiri, maupun dalam kedudukannya sebagai fenomena yang saling terkait di antara fenomena lainnya, baik sebagai penyebab maupun sebagai akibat. Sehingga rumusan masalah merupakan formulasi dari pertanyaan penelitian, yang artinya merupakan kesimpulan pertanyaan yang terkandung dalam pertanyaan penelitian". ${ }^{42}$

Rumusan masalah merupakan formulasi pertanyaan penelitian atau kesimpulan pertanyaan yang terkandung dalam pertanyaan penelitian.

Langkah selanjutnya yaitu menyusun tujuan penelitian.

"Tujuan penelitian adalah untuk mengetahui sesuatu yang pada tingkat tertentu dipercaya sebagai sesuatu yang benar. Ia bertitik tolak dari pertanyaan yang disusun dalam bentuk masalah penelitian. Untuk menjawab pertanyaan itu disusun suatu jawaban sementara yang kemudian dibuktikan melalui penelitian empiris". ${ }^{43}$

Tujuan penelitian adalah jawaban sementara yang kemudian dibuktikan melalui penelitian empiris. Dosen memiliki kemampuan menolong mahasiswa dalam merumuskan tujuan penelitian. Kemudian, mengumpulkan teori-teori yang berkaitan dengan masalah yang akan dibahas dan menggunakan teori-teori yang telah digunakan untuk memecahkan masalah dan menarik kesimpulan.

3. Pengabdian Kepada Masyarakat

a. Dosen Melakukan Pengabdian Masyarakat Sesuai Ilmu yang Ditekuni

Dasar pelaksanaan tugas dosen dalam Undang-Undang No. 14 Tahun 2005 Tentang

Guru dan Dosen. Salah satu tugas dosen adalah melakukan pengabdian kepada masyarakat. "Kegiatan ini adalah salah satu kewajiban dosen yang harus dilaksanakan sebagai tanggung

\footnotetext{
${ }^{41}$ Juliansyah Noor, Metodologi Penelitian: Skripsi, Tesis, Disertasi, dan Karya Ilmiah (Jakarta: Kencana, 2017), 245.

${ }^{42}$ Firdaus dan Fakhry Zamzam, Aplikasi Metodologi Penelitian (Yogyakarta: Deepublish, 2018), 40 .
}

${ }^{43}$ W. Gulo, Metodologi Penelitian (Jakarta: Grasindo, 2012), 56, 
jawab sosial yang harus diemban oleh tenaga edukasi". ${ }^{44}$ Pengabdian kepada masyarakat adalah tanggung jawab sosial dosen untuk memberikan sumbangsih sesuai dengan ilmu yang ditekuni.

\section{b. Dosen Melakukan Kegiatan Masyarakat Dengan Tujuan Yang Jelas}

Dosen melakukan pengabdian kepada masyarakat dalam berbagai wujud kegiatan. Berbagai kegiatan yang akan dilakukan antara lain: memberikan pelatihan-pelatihan, melakukan pembimbingan, memberikan pengajaran dan memberikan sumbangsih berupa tulisan-tulisan yang membangun. Dosen diharapkan memiliki kepekaan terhadap kebutuhan lingkungan baik secara moral maupun sosial. Kepekaan ini diwujudkan dengan suatu tindakan konkrit yang dapat diukur dan berguna bagi masyarakat. Dosen dapat melibatkan mahasiswa dalam pengabdian kepada masyarakat. Selain melibatkan mahasiswa dosen juga melakukan kegiatan pengabdian kepada masyarakat sesuai dengan bidang yang ditekuninya.

Tujuan dosen yang melakukan kegiatan pengabdian kepada masyarakat dapat meningkatkan kecerdasan emosionalnya karena memiliki kepedulian dan empati yang dibutuhkan masyarakat. Kegiatan pengabdian kepada masyarakat ini dapat dilakukan secara instutusional atau secara individual. Perguruan Tinggi berkewajiban menyediakan sarana dan prasarana bagi kegiatan pengabdian kepada masyarakat ini. Hal ini memberikan dampak institusi pendidikan merasa sebagai bagian dari masyarakat dan bukan terpisah dari masyarakat.

\section{HASIL PENELITIAN}

Impelementasi Tri Dharma Perguruan Tinggi membahas tentang tugas pokok dosen yaitu: melakukan pengajaran, penelitian dan pengabdian kepada masyarakat. Pengajaran berkaitan dengan penyusunan bahan ajar, menyusun RPP (Rencana Pelaksanaan Pembelajaran, memilih metode, memilih strategi pembelajaran, menggunakan media pembelajaran, memahami psikologis mahasiswa. Penelitian berkaitan dengan dosen menyusun penelitian mandiri dan menyusun penelitian bersama dengan mahasiswa untuk memberikan pembimbingan. Pengabdian masyarakat, dosen menyusun kegiatan pengabdian masyarakat dengan tujuan yang jelas dan dosen melakukan kegiatan masyarakat sesuai dengan ilmu yang dikuasai.

Uji hipotesis deskriptif menggunakan nilai hipotesis yang diperoleh dari skor empiris dibagi dengan skor ideal dikali 100\%, sebab uji t tidak berlaku, karena penelitian ini merupakan penelitian populasi. Uji t hanya berlaku pada penelitian sampel. Adapun bunyi hipotesis pertama adalah Diduga Implementasi Tri Dharma Perguruan Tinggi oleh Dosen PAK Tahun Ajaran 2018/2019 di STT "Kristus Alfa Omega" Semarang dalam kategori sedang atau sama dengan $60 \%$ dari nilai maksimum.

$$
\begin{aligned}
& \text { Nilai_Hipotesis }=\frac{\text { Skor_Empiris }}{\text { Skor_Ideal }} \times 100 \% \\
& \text { Nilai_Hipotesis }=\frac{3154}{19 \times 4 \times 50} \times 100 \% \\
& \text { Nilai_Hipotesis }=\frac{3154}{3800} \times 100 \% \\
& \text { Nilai_Hipotesis }=0,83 \times 100 \% \\
& \text { Nilai_Hipotesis }=83 \%
\end{aligned}
$$

${ }^{44}$ Sanusi Hamid, Manajemen Sumber Daya Manusia Lanjutan (Yogyakarta: Deepublish, 2014), 11. 
Hasil perhitungan diperoleh nilai hipotesis sebesar $83 \%$ dari nilai maksimum, hal ini membuktikan bahwa hipotesis yang berbunyi "Diduga Implementasi Tri Darma Perguruan Tinggi oleh Dosen PAK Tahun Ajaran 2018/2019 di STT "Kristus Alfa Omega" Semarang dalam kategori sedang atau sama dengan $60 \%$ dari nilai maksimum" tidak diterima.

\section{E. KESIMPULAN}

Impelementasi Tri Dharma Perguruan Tinggi membahas tentang tugas pokok dosen yaitu: melakukan pengajaran, penelitian dan pengabdian kepada masyarakat. Pengajaran berkaitan dengan penyusunan bahan ajar, menyusun RPP (Rencana Pelaksanaan Pembelajaran, memilih metode, memilih strategi pembelajaran, menggunakan media pembelajaran, memahami psikologis mahasiswa. Penelitian berkaitan dengan dosen menyusun penelitian mandiri dan menyusun penelitian bersama dengan mahasiswa untuk memberikan pembimbingan. Pengabdian masyarakat, dosen menyusun kegiatan pengabdian masyarakat dengan tujuan yang jelas dan dosen melakukan kegiatan masyarakat sesuai dengan ilmu yang dikuasai.

Adapun bunyi hipotesis pertama adalah Diduga Implementasi Tri Darma Perguruan Tinggi oleh Dosen PAK Tahun Ajaran 2018/2019 di STT "Kristus Alfa Omega" Semarang dalam kategori sedang atau sama dengan $60 \%$ dari nilai maksimum tidak diterima karena hasil perhitungan di atas diperoleh nilai hipotesis sebesar $83 \%$ dari nilai maksimum.

Berdasarkan penelitian item yang menyatakan "Saya dilibatkan penelitian bersama dengan dosen", sebanyak $8 \%$ hal ini mengindikasikan bahwa dosen kurang melibatkan mahasiswa dalam penelitian. Item yang menyatakan, "Saya membaca penelitian dosen di jurnal SHIFT KEY", sebanyak 4\% hal ini mengindikasikan bahwa Mahasiswa Program Studi Pendidikan Agama Kristen tidak pernah membaca penelitian dosen dalam SHIFT KEY, yaitu jurnal penelitian STT "Kristus Alfa Omega Semarang”.

\section{DAFTAR PUSTAKA}

Ali, Mohammad, Pendidikan Untuk Pembangunan Nasional: Menuju Bangsa Indonesia yang Mandiri dan Berbudaya Saing Tinggi (Jakarta; Intima, 2009).

Amirudin Mahmud, Guru Tak Boleh Sejahtera - Catatan dan Refleksi Seorang Pendidik (Yogyakarta: Deepublish, 2018).

Awalludin, Pengembangan Buku Teks Sintaksis Bahasa Indonesia (Yogyakarta: Deepublish, 2017).

Astiti, Kadek Ayu, Evaluasi Pembelajaran (Yogyakarta, ANDI, 2017).

C.S Widodo \& Jasmadi STP, Panduan Menyusun Bahan Ajar Berbasis Kompetensi, Jakarta: Elex Media Komputindo, 2008).

Djiwandono, Patrisius Istiarto, Meneliti Itu Tidak Sulit: Metodologi Penelitian Sosial dan Pendidikan Bahasa (Yogyakarta: Deepublish 2015).

Firdaus dan Fakhry Zamzam, Aplikasi Metodologi Penelitian (Yogyakarta: Deepublish, 2018). Firdiyanto, Kaum Intelektual di Bawah Kaki Kekuasaan, (Lampung, Gre Publishing, 2017).

Gulo, W., Metodologi Penelitian (Jakarta: Grasindo, 2012).

Hamdi Asep Saiful, E Bahruddin, Metode Penelitian Kuantitaif Aplikasi dalam Pendidikan (Yogyakarta; Deepublish, 2014).

Hamdi, Asep Saiful, E Bahruddin, Metode Penelitian Kuantitaif Aplikasi dalam Pendidikan (Yogyakarta; Deepublish, 2014).

Hamid, Sanusi, Manajemen Sumber Daya Manusia Lanjutan (Yogyakarta, Deepublish, 2014).

Julia, . Isro'atun, Indra Safari, Prosiding Seminar Nasional, (Sumedang, UPI Sumedang Press,2018). 
Miarso, Yusufhadi, Menyemai Benih Teknologi Pendidikan, (Jakarta: Prenadamedia Group, 2011).

Noor, Juliansyah, Metodologi Penelitian: Skripsi, Tesis, Disertasi, dan Karya Ilmiah (Jakarta: Kencana, 2017).

Prastowo, Andi, Menyusun Rencana Pelaksanaan Pembelajaran ( RPP) Tematik Terpadu, (Jakarta: Kencana, 2017).

Prawiradilaga, Dewi Salma, Mozaik Teknologi Pendidikan E-Learning, (Jakarta: Prenadamedia, 2016).

Rifma, Optimalisasi Pembinaan Kompetensi Paedagogik Guru (Jakarta: Kencana, 2016).

Saifuddin, Pengelolaan Pembelajaran Teoritis dan Praktis, (Yogyakarta: Deepublish, 2014).

Sanjaya, Wina dan Andi Budimanjaya, Paradigma Baru Mengajar, (Jakarta: Kencana, 2017).

Sanjaya, Wina, Paradigma Baru Mengajar, (Jakarta: Kencana, 2017).

Sarwono Jonathan, Pintar Menulis Karangan Ilmiah (Yogyakarta: Andi, 2010).

Satrianawati, Media dan Sumber Belajar, (Yogyakarta: Deepublish, 2018).

Setyosari, Punaji, Metode Penelitian dan Pengembangan (Jakarta: Prenada Media Group,2016).

Siregar, Sofyan, Statistik Parametrik Untuk Penelitian Kuantitatif (Jakarta; Bumi Aksara, 2014).

Sugiyono, Metode Penelitian Pendidikan (Bandung: Alfabeta, 2010).

Sumar, Warni Tune, Strategi Pembelajaran dalam Implementasi Kurikulum Berbasis Soft Skill, (Yogyakarta; Deepublish, 2016).

Sunaengsih, Cucun, Buku Ajar Pengelolaan Pendidikan, (Sumedang, UPI Sumedang Press, 2017).

Susanto, Ahmad, Bimbingan dan Konseling di Sekolah: Konsep, Teori dan Aplikasinya, (Jakarta: Prenadamedia Group, 2018).

Susanto, Ahmad, Teori Belajar dan Pembelajaran di Sekolah Dasar, (Jakarta: Prenadamedia Group, 2016).

Suyanto dan Asep Jihad, Menjadi Guru Profesional, (Jakarta: Erlangga,2013).

Thalib, Syamsul Bachri, Psikologi Pendidikan Berbasis Analisis Empiris Aplikatif, (Jakarta; Kencana, 2010).

Westwood Peter S., What Teacher Needs To Know About Teaching Method (Victoria, Acer Press, 2008).

Whitton, Diana, Teaching and Learning Strategies, (Melbourne, Cambridge University Press, 2015).

Winastwan, Gora dan Sunarto, Pakematik: Strategi Pembelajaran Inovatif Berbasis TIK (Jakarta; Elex Media Komputindo, 2010).

Yount'Rich, Reseach Design and Statistica Analysis For Ministry (Fort Worth: SWBTS, 1990).

Yusuf, A. Muri, Assesmen dan Evaluasi Pendidikan (Jakarta: Kencana, 2017). 